\title{
SZYMON STUŁKOWSKI \\ Od mistycznych korzeni do apostolskich owoców. Dynamika trzyletniego programu duszpasterskiego dla Kościoła w Polsce (2010-2013)
}

Wielu obserwatorów życia Kościoła w Polsce wspomina z nostalgią program duszpasterski Prymasa Tysiąclecia, związany z Wielką Nowenną przed Milenium Chrztu Polski. Tamte działania, przygotowane przez kardynała Stefana Wyszyńskiego i jego najbliższych współpracowników, obejmowały wszystkie diecezje i parafie w Polsce. Była to głęboka wizja odnowy moralnej narodu polskiego przez osobiste zjednoczenie wiernych z Jezusem, poprzez wstawiennictwo Najświętszej Maryi Panny, Królowej Polski. Sytuacja społeczno-polityczna tamtych lat sprzyjała konsolidacji działań duszpasterskich kościołów lokalnych, parafii i rodzin ludzi wierzących, które wzmacniały swoją chrześcijańską tożsamość, odkrywając korzenie, z których wyrastały oraz umacniały się w przekonaniu, że wrogi człowiekowi i Kościołowi system nie jest w stanie zniszczyć tego, co zbudowane jest na fundamencie wiary w Boga.

Przed wielkim Jubileuszem Roku 2000 Jan Paweł II w liście apostolskim Tertio millennio adveniente ${ }^{1}$ zaproponował Kościołowi powszechnemu wspólną drogę przygotowań, która prowadziła przede wszystkim do odnowy osobistej relacji ze Zbawicielem wszystkich ludzi dobrej woli, którzy podjęli propozycję papieża, jak również odnowy oblicza Kościoła oraz społeczeństw. Na wszystkich kontynentach świata, na różny sposób realizowano wytyczony przez Jana Pawła

Szymon S T U Ł K O W S K I, ks. dr, adiunkt w Zakładzie Teologii Pastoralnej Wydziału Teologicznego Uniwersytetu im. Adama Mickiewicza w Poznaniu, sekretarz Komisji Duszpasterstwa Konferencji Episkopatu Polski, e-mail: szymons@amu.edu.pl

${ }^{1}$ Por. J a n P a w e 1 I I: List apostolski Tertio millennio adveniente. „L'Osservatore Romano". Wydanie polskie. R. 15: 1994 nr 12 s. 4-22. 
II program duszpasterski, prowadzący Kościół ku nowemu tysiącleciu chrześcijaństwa. Po przejściu przez próg nowego tysiąclecia papież dokonał podsumowania czasu przygotowania oraz samego Wielkiego Jubileuszu w liście apostolskim Novo millennio ineunte, w którym zachęcił biskupów do analizowania życia wiary na różnych kontynentach, w regionach czy krajach, by odpowiedzią na sytuacje życia ludzi był dostosowany do potrzeb Kościoła i społeczeństw program duszpasterski. Jednocześnie papież zaznaczył, że programem tym jest zawsze Jezus Chrystus, którego należy poznać, pokochać i naśladować. Nie trzeba zatem wyszukiwać »owego programu«. Program już istnieje: ten sam co zawsze, zawarty $w$ Ewangelii $i$ w żywej Tradycji. Jest on skupiony $w$ istocie rzeczy wokót samego Chrystusa, którego mamy poznawać, kochać i naśladować, aby żyć w Nim życiem trynitarnym i z Nim przemieniać historię, aż osiagnie swa petnię $w$ niebiańskim Jeruzalem. Program ten nie zmienia się mimo uptywu czasu i ewolucji kultur, chociaż bierze pod uwage epoke i kulture, aby możliwy byt prawdziwy dialog $i$ rzeczywiste porozumienie. Ten właśnie niezmienny program jest naszym programem na trzecie tysiaclecie ${ }^{2}$. W tamtych latach w Polsce program duszpasterski polegał na odczytywaniu zadań, jakie Jan Paweł II wskazywał Kościołowi do realizacji. Ówczesny przewodniczący Komisji Duszpasterstwa Ogólnego, arcybiskup katowicki Damian Zimoń, wielokrotnie powtarzał, że program duszpasterski pisze nam Jan Paweł II. Obserwatorzy i recenzenci kościelnej sceny w Polsce zapytywali nieraz, czy gdy papieża-Polaka zabraknie, będziemy wiedzieli jak żyć i jaką drogą iść w przyszłość? Nawet wewnątrz wspólnoty kościelnej rodziły się obawy, że bez Jana Pawła II, który niewątpliwie bardzo wyraźnie oddziaływał na kształt Kościoła w swojej ojczyźnie, nie potrafimy samodzielnie odpowiedzieć na pytanie, jakim Kościołem chcemy być dzisiaj w Polsce?

\section{W poszukiwaniu wizji}

Kiedy w 2006 r. przewodniczenie Komisji Duszpasterstwa Konferencji Episkopatu Polski objął metropolita poznański, arcybiskup Stanisław Gądecki, dokończył on rozpoczęty cykl programu duszpasterskiego na lata 2006-2010, którego hasłem były słowa: „Kościół niosący Ewangelię nadziei”, a następnie szukał nowej wizji dla działań pastoralnych w Polsce. Jesienią $2006 \mathrm{r}$ arcybiskup poznański zwrócił się listownie do środowiska pastoralistów polskich o pomoc, stwierdzając bardzo dosadnie, że nie wyobraża sobie, by przyszły program duszpasterski był wypracowany bez udziału teologów, którzy w swej pracy naukowej i badawczej zajmują się na co dzień sposobami urzeczywistnianiem się Kościoła i realizowania Jego misji zbawczej. Apel przewodniczącego Komisji Duszpasterstwa został odczytany przez środowisko pastoralistów polskich jako dobry sygnał, wskazujący otwartość biskupów na doświadczenia tego środowiska teolo-

\footnotetext{
${ }^{2}$ J a n P a w e 1 I I: List apostolski Novo millennio ineunte. Watykan $2001 \mathrm{nr} 29$.
} 
gicznego. Arcybiskup Gądecki zaprosił do pracy w Komisji Duszpasterstwa profesorów teologii pastoralnej reprezentujących najważniejsze środowiska teologiczne w Polsce ${ }^{3}$. Ówczesny przewodniczący Polskiego Stowarzyszenia Pastoralistów i Duszpasterzy im. Jana Pawła II, ks. prof. dr hab. Jan Przybyłowski wraz ze swoim zastępcą, ks. prof. dr hab. Edmundem Robkiem, przybyli do Poznania, aby osobiście omówić z przewodniczącym Komisji Duszpasterstwa zasady współpracy. Podczas spotkania zaplanowano wspólne sympozjum, które miało być zorganizowane przez oba podmioty: Komisję Duszpasterstwa oraz stowarzyszenie, którego celem byłoby podjęcie refleksji nad planowaniem duszpasterskim w Kościele. Ustalono, że odbędzie się ono 23-24 kwietnia 2007 r. w Sieradzu. Sympozjum, oprócz omówienia ustalonego wcześniej zagadnienia, miało na celu także rozeznanie, którzy z pastoralistów polskich zainteresowani są współpracą z Komisją Duszpasterstwa. Sieradzkie spotkanie przewodniczącego Komisji Duszpasterstwa ze środowiskiem pastoralistów polskich przyniosło bardzo dobre owoce. Wnioski z sympozjum posłużyły do naszkicowania wstępnych inicjatyw, służących wypracowaniu wizji programu duszpasterskiego dla Kościoła w Polsce na okres po roku $2010^{4}$. Ujawniła się także grupa pastoralistów, gotowych zaangażować się w wypracowanie wizji i szczegółów programu.

Przewodniczący Komisji Duszpasterstwa zwrócił się z prośbą do członków Konferencji Episkopatu Polski, szczególnie do biskupów diecezjalnych, oraz do członków i konsultorów komisji o nadesłanie propozycji zagadnień, które powinny być uwzględnione w przyszłym programie duszpasterskim. Ostatecznie zebrano kilkanaście propozycji, które stały się punktem wyjścia dla prac grupy pastoralistów współpracujących z metropolitą poznańskim. Wybrano propozycję z tematem wiodącym „Kościół domem i szkołą komunii”, która po przedstawieniu przez przewodniczącego Komisji Duszpasterstwa na posiedzeniu Konferencji Episkopatu Polski została zatwierdzona do realizacji.

\section{Ku ostatecznej redakcji programu}

Kolejnym etapem wypracowania wizji programu duszpasterskiego było spotkanie grupy zainteresowanych tą pracą pastoralistów w rezydencji arcybiskupa poznańskiego. Uczestnicy spotkania przeanalizowali zebrane wcześniej propozycje oraz przygotowali własne, które, według ich opinii, powinny być uwzględ-

\footnotetext{
${ }^{3}$ Konsultorami Komisji Duszpasterstwa Konferencji Episkopatu Polski zostali profesorowie teologii pastoralnej: ks. prof. dr hab. Bronisław Mierzwiński z Uniwersytetu Kardynała Stefana Wyszyńskiego w Warszawie, ks. prof. dr hab. Maciej O st row s k i z Uniwersytetu Papieskiego Jana Pawła II w Krakowie oraz ks. prof. dr hab. Wiesław Pr z y g o d a z Katolickiego Uniwersytetu Lubelskiego.

${ }^{4}$ Przedłożenia prezentowane na sympozjum Polskiego Stowarzyszenia Pastoralistów i Duszpasterzy im. Jana Pawła II w Sieradzu (23-24.04.2007) opublikowane zostały w „Teologii Praktycznej" (T. 9: 2008).
} 
nione w przyszłym programie duszpasterskim. Zespół przygotował wizję wieloletniego programu, którego myślą przewodnią stały się słowa z listu apostolskiego Novo millennio ineunte Jana Pawła II: Czynić Kościót domem i szkoła komunii (NMI 43). Pastoraliści pracujący na wizją programu byli zgodni, że zadanie, jakie papież wytyczył dla Kościoła na nowe tysiąclecie, winno być realizowane długofalowo i stopniowo. Zaproponowano dwudziestoletni program duszpasterski, który podzielony na czteroletnie okresy, byłby realizowany w pięciu fazach. Dla wszystkich pięć etapów sformułowano tematy, jednakże szczegółowo opracowano tylko pierwszy, czyli cztery najbliższe lata. Po zakończeniu pierwszej fazy należałoby dokonać ewaluacji, która pomogłaby zredagować cele i treści następnego etapu programu. Przewodniczący Komisji Duszpasterstwa zaaprobował przygotowaną wizję programu i postanowił zaprezentować ją na posiedzeniu Konferencji Episkopatu Polski. Tam okazało się, ku zdziwieniu metropolity poznańskiego, że biskupi nie są gotowi myśleć tak perspektywicznie o pastoralnej przyszłości Kościoła w Polsce. Propozycja została skrytykowana i odrzucona. Główne argumenty za odrzuceniem tego projektu dotyczyły jego wieloletniego charakteru. Padały stwierdzenia podnoszące, że my tego nie dożyjemy lub nie krępujmy rąk tym, którzy przyjda po nas. Ostatecznie zdecydowano, że przyszły program: „Kościół domem i szkołą komunii”, będzie realizowany przez trzy lata (2010-2013). Trudno było znaleźć uzasadnienie, dlaczego zdecydowano się na trzy, a nie na pięć lat. Krytycznie odniósł się do tej decyzji profesor teologii pastoralnej z Poznania, ks. Adam Przybecki, który napisał: zredukowanie do trzech lat pierwotnego projektu programu duszpasterskiego, który zamierzony byt na dwadzieścia lat, do roku 2031, jest świadectwem niezrozumienia wagi i znaczenia problematyki, zawartej $w$ haśle programu. Nie jest ona bowiem nośnym jedynie i medialnie atrakcyjnym sloganem, ale dotyka samej istoty tego, co winniśmy traktować jako odpowiedź na stawiane po przetomie roku 1989 ciagle pytanie: jak być Kościołem w Polsce dzisiaj. Tymczasem odnieść można wrażenie, że po $d w u d z i e s t u$ latach od upadku komunizmu $w$ naszym myśleniu pokutuje jeszcze duch realnego socjalizmu, w którym zamiast prawdziwej czekolady, serwowano produkty czekoladopodobne. Podobnie w odniesieniu do planowania duszpasterskiego - zamiast programu z prawdziwego zdarzenia, otrzymujemy produkt programopodobny ${ }^{5}$. Kolejnym etapem pracy nad programem było robocze spotkanie pastoralistów i metropolity poznańskiego, podczas którego opracowano wizję i szczegóły trzyletniego programu duszpasterskiego dla Kościoła w Polsce.

${ }^{5}$ A. P r z y b e c k i: »Czynić Kościót domem i szkoła komunii«. Zadania dla Kościoła w Polsce. W: W komunii Bogiem. Kościót domem szkoła komunii. Program duszpasterski Kościoła w Polsce na lata 2010-2013. Red. Sz. S t u ł k o w s k i. Poznań 2010 s. 213-214. 


\section{Drogi realizacji - pierwszy etap}

$\mathrm{Z}$ zaplanowanego pierwotnie wieloletniego programu duszpasterskiego należało przygotować krótki, na trzy lata. W trakcie dyskusji i poszukiwań zdecydowano, że pierwszy rok pracy duszpasterskiej poświęcony będzie duchowym korzeniom, a dwa następne apostolskim owocom. Określono cele ogólne programu duszpasterskiego „Kościół domem i szkołą komunii” (2010-2013), którymi są: odkrywanie i pogłębienie duchowości komunii, odnowa i wzmocnienie struktur komunijnych Kościoła, krzewienie duchowości komunii oraz duszpasterska troska o rodzinę. Program duszpasterski miał inspirować wierzących do odkrywania istoty komunii, czyli jedności człowieka z Bogiem, by dalej budować i umacniać na tym doświadczeniu wiary struktury komunijne i wreszcie czynić je narzędziem ewangelizacji. Duchowe korzenie rozumiane były jako głęboka, autentyczna relacja człowieka z Bogiem.

Pierwszy etap pracy pastoralnej zatytułowany „W komunii z Bogiem” był realizowany w latach 2010/2011. W pierwszym roku nowego programu duszpasterskiego stawiano sobie następujące cele: odkrywanie Boga objawiającego się w słowie Bożym, inicjacja do dojrzałego przyjęcia słowa Bożego, odnawianie i pogłębianie osobistej relacji z Bogiem, kształtowanie wspólnotowego wymiaru życia duchowego oraz duszpasterska troska o rodzinę.

Ustalono także treści, które należało podjąć przy realizacji programu. Były to: słowo Boże, osobowa więź chrześcijanina z Bogiem, wspólnotowy wymiar chrześcijańskiego życia duchowego oraz ukazanie Maryi jako Mistrzyni życia duchowego.

Komisja Duszpasterstwa określiła także sposoby realizacji wskazanych celów i treści. Zaproponowano tworzenie w diecezjach Szkół Słowa Bożego i modlitwy, proponując wykorzystanie bogatych doświadczeń Dzieła Biblijnego, Ruchu Światło-Życie, a także Szkół Nowej Ewangelizacji działających w Polsce. Komisja Duszpasterstwa zdecydowała, by propozycje zawarte w programie duszpasterskim wsparły działania, podejmowane $\mathrm{w}$ wielu diecezjach $\mathrm{w}$ ramach erygowanego we wrześniu 2005 r. przez Konferencję Episkopatu Polski stowarzyszenia kościelnego Dzieło Biblijne im. Jana Pawła II. Głównym celem tej organizacji jest krzewienie duchowości i kultury biblijnej w Polsce. Osoby zabiegające o powołanie stowarzyszenia wiedziały, że takiej pracy duszpasterskiej nam brakuje i podjęcie jej jest pilnym zadaniem, jakie stoi przed Kościołem w naszej ojczyźnie. Wszędzie tam, gdzie udało się w diecezjach powołać do istnienia Szkoły Słowa Bożego, zaobserwowano duże zainteresowanie osób dorosłych proponowaną formacją biblijną. W wielu miejscach w Polsce można było usłyszeć opinie, że Dzieło Biblijne znalazło pewną „niszę” na pastoralnej mapie Pol- 
ski i skutecznie ją zagospodarowuje ${ }^{6}$. Drugim po kształtowaniu duchowości biblijnej działaniem, służącym budowaniu komunii z Bogiem, było wskazanie w programie duszpasterskim potrzeby tworzenia w diecezjach centrów formacji duchowej. Twórca i dyrektor Centrum Formacji Duchowej Salwatorianów w Krakowie, ks. Krzysztof Wons SDB, wskazał na potrzebę indywidualnej i pogłębionej formacji w Kościele oraz tworzenia i posiadania w diecezjach centrów formacji duchowej. Na przykładzie kilkunastoletniej posługi w Krakowie pokazał dynamikę centrów formacji duchowej, która ma swój początek w stworzeniu domu, stającym się centrum duchowości, by następnie rozwijać je w kierunku szkoły duchowości i w końcu stać się szkołą formacji duchowej

Już na tym przykładzie widać wyraźnie, jak niefortunną była decyzja ograniczenie programu duszpasterskiego do trzech lat. Po pierwszym roku realizacji programu jeden z członków Komisji Duszpasterstwa wyraźnie zaznaczył, że nie da się w jednym roku utworzyć w diecezji centrum formacji duchowej dla osób dorosłych. Takie działanie musi być rozumiane jako proces, do którego realizacji potrzeba sporo czasu ${ }^{8}$. W budowaniu komunii z Bogiem program duszpasterski wskazał także na potrzebę prowadzenia katechezy inicjacyjnej w parafiach, jak również na wspólnotowe przeżywanie sakramentów świętych, proponując wprowadzanie w diecezjach i parafiach nabożeństw pokutnych. Myśląc o komunijnym wymiarze modlitwy zachęcano kapłanów do wspólnotowego - razem z osobami świeckimi - celebrowania Liturgii godzin. Na uwagę zasługuje akcent, jaki w programie duszpasterskim położono na pracę z Biblią oraz na formację ludzi dorosłych. Świadczy to o dobrym rozeznaniu stanu polskiej religijności i wskazaniu na konieczność formacji dorosłych, służącej przechodzeniu od pobożności opartej na tradycji do religijności świadomego wyboru Boga. Tak wybrany „punkt ciężkości” programu absolutnie nie umniejsza znaczenia Eucharystii czy innych sakramentów w budowaniu komunii z Bogiem, czyli w „zakorzenianiu” człowieka w tajemnicę Boga.

\section{Aby Kościół stawał się domem - drugi etap}

Drugi rok programu duszpasterskiego nosił hasło: „Kościół naszym domem”. Wśród celów programu na lata 2011/2012 wskazano: pomoc w zrozumie-

\footnotetext{
${ }^{6}$ Por. H. W i t c z y k: Krzewienie duchowości biblijnej. Dotychczasowe doświadczenia Dzieła Biblijnego im. Jana Pawła II w Polsce i perspektywy na przyszłość. W: W komunii Bogiem. Kościót domem szkoła komunii, tamże, s. 226-242.

${ }^{7}$ Por. K. W o n s: Potrzeba centrów formacji duchowej w diecezjach. W: W komunii Bogiem. Kościót domem szkoła komunii, tamże, s. 243-261.

${ }^{8}$ Była to uwaga bpa Edwarda D a j c z a k a, ordynariusza diecezji koszalińsko-kołobrzeskiej, członka Komisji Duszpasterstwa Konferencji Episkopatu Polski. Dyskusja, która wywiązała się po tej wypowiedzi, wskazywała na świadomość członków komisji, że zbyt mało czasu mamy na realizację ambitnych celów, jakie proponuje program duszpasterski.
} 
niu tajemnicy Kościoła, ukazanie komunii jako dzieła Ducha Świętego, umocnienie ducha ekumenizmu, pomoc w odkrywaniu własnego miejsca w Kościele, pogłębianie ducha zaangażowania i współodpowiedzialności za Kościół oraz odnawianie i budowanie struktur komunijnych.

Komisja Duszpasterstwa zaproponowała również treści, które miały zostać podjęte w pracy duszpasterskiej tego roku. Przede wszystkim zwrócono uwagę na miłość, jako zasadę życia Kościoła. Podkreślono potrzebę odkrywania Kościoła, jako Ludu Bożego prowadzonego przez Ducha Świętego, roli Maryi we wspólnocie Kościoła, a także ekumenizmu. Wskazano na znaczenie powołań, darów i charyzmatów w Kościele oraz na ducha służby i ofiary w budowaniu wspólnoty.

Wypracowano zarazem sposoby realizacji wskazanych wyżej celów i treści. Zaproponowano pogłębianie ducha współpracy między duchowieństwem, osobami życia konsekrowanego i wiernymi świeckimi. Zwrócono uwagę na potrzebę formacji animatorów świeckich, na większą obecność i zaangażowanie świeckich w duszpasterstwie parafialnym, zwłaszcza w katechezie sakramentalnej, liturgii, a także w działalności charytatywnej. Zwrócono też uwagę na działalność rad duszpasterskich i rad ekonomicznych w parafiach oraz rad kapłańskich i rad duszpasterskich w diecezjach. Specjalna propozycja dotyczyła także biskupów diecezjalnych, którym zaproponowano tworzenie rad społecznych, służących analizowaniu wydarzeń i problemów dotyczących różnych przestrzeni życia społecznego 9 .

W drugim roku realizacji programu duszpasterskiego mamy już do czynienia $\mathrm{z}$ apostolskimi owocami duchowych korzeni. Autentyczna komunia z Bogiem prowadzi człowieka do relacji z bliźnimi, do doświadczenia komunii z siostrami i braćmi. Papież Benedykt XVI w encyklice Deus caritas est naucza: stwierdzenie o miłości Boga staje się kłamstwem, jeżeli człowiek zamyka się na bliźniego czy wręcz go nienawidzi. Miłość bliźniego jest droga do spotkania również Boga, a zamykanie oczu na bliźniego czyni go ślepym również na Boga ${ }^{10}$. Doświadczenie duchowych korzeni komunii z Bogiem owocuje w życiu chrześcijanina głębszym poznaniem drugiej osoby, uzdalnia do odkrywania w niej oblicza Bożego. W tej samej encyklice Benedykt XVI konkluduje: Jeżeli w moim życiu brak zupetnie kontaktu z Bogiem, moge widzieć w innym człowieku zawsze jedynie innego i nie potrafię rozpoznać w nim obrazu Boga. Jeżeli jednak w moim życiu nie zwracam zupetnie uwagi na drugiego człowieka, starajac się być jedynie "pobożnym" $i$ wypetniając swoje "religijne obowiązi«, oziębia się także moja relacja z Bo-

\footnotetext{
${ }^{9}$ Por. Sz. S t u 1 k o w s k i: Schemat programu duszpasterskiego. Kościót naszym domem. W: Kościót naszym domem. Kościół domem i szkoła komunii. Program duszpasterski Kościoła w Polsce na lata 2010-2013. Red. Sz. S t u ł k o w s k i. Poznań 2011 s. 17-18.

${ }^{10}$ B e n e d y k t X V I: Encyklika Deus caritas est. Watykan 2005 nr 16.
} 
giem. Jest ona wówczas tylko "poprawna«, ale pozbawiona miłości. Jedynie stużba bliźniemu otwiera mi oczy na to, co Bóg czyni dla mnie, i na to, jak mnie $k o c h a^{11}$. Papież wskazuje na wzajemną zależność duchowych korzeni i apostolskich owoców. Tak, jak bez autentycznego zakorzenienia w Bogu nie można mówić o prawdziwej wspólnocie między ludźmi, tak też bez otwarcia się na siostry i braci, nie będzie możliwe doświadczenie prawdziwego zjednoczenia z Bogiem.

Komisja Duszpasterstwa zaproponowała w drugim roku programu działania służące pogłębianiu struktur komunijnych, począwszy od tej najbliższej każdemu człowiekowi, jaką jest rodzina. Propozycja wprowadzenia Karty Dużej Rodziny, zaprezentowana przez Związek Dużych Rodzin $3+$, znalazła w Polsce wielu zwolenników i sprowokowała liczne środowiska samorządowe do dyskusji na ten temat, a niekiedy nawet do wprowadzenia tego rozwiązania w życiu miast $\mathrm{i}$ $\operatorname{gmin}^{12}$. Celem strategicznym drugiego etapu programu stało się wprowadzenie czy ożywienie struktur komunijnych w parafiach. Szczególną uwagę zwrócona na parafialne rady duszpasterskie ${ }^{13}$. Mimo, iż w tym roku świętujemy uroczyście 50. rocznicę otwarcia Soboru Watykańskiego II, ciągle jeszcze w Polsce te podstawowe struktury komunijne w parafiach są rzadkością. Dotychczas nie dopracowaliśmy się jeszcze badań socjologicznych analizujących tę rzeczywistość. Aby pobudzić środowiska wszystkich polskich diecezji do refleksji na ten temat, zorganizowano pod koniec drugiego roku realizacji programu duszpasterskiego, pierwszy Krajowy Kongres Diecezjalnych Rad Duszpasterskich ${ }^{14}$. W trakcie przygotowań do kongresu, na zlecenie Komisji Duszpasterstwa, przeprowadzono badania funkcjonowania tych diecezjalnych gremiów Kościoła w Polsce. Okazało się, że nie we wszystkich diecezjach biskupi otoczeni są gronem wiernych, służących swoim doświadczeniem w realizacji ich misji pasterskiej. W kongresie, mimo wielu zaproszeń i zachęt, nie wzięło udziału pięć diecezji. Świadczy to dobitnie o stanie życia wspólnotowego Kościoła w Polsce. We wrześniu 2013 r. planowany jest w Licheniu pierwszy Krajowy Kongres Parafialnych Rad Duszpasterskich. To kolejny środek służący do mobilizacji wspólnot parafialnych w realizacji założeń programu. Należy ufać, że przyczyni się on skutecznie do ożywienia tych struktur w polskich parafiach.

\footnotetext{
${ }^{11}$ Tamże, nr 18.

${ }^{12}$ Por. I. B y 1 i c k a: Karta Dużej Rodzin, W: Kościół naszym domem. Kościót domem i szkota komunii, dz. cyt., s. 307-321.

${ }^{13}$ Por. W. M u s i o 1, K. P i e c h a c z e k: Formacja Parafialnych Rad Duszpasterskich, W: Kościół naszym domem. Kościót domem i szkoła komunii, tamże, s. 242-253.

${ }^{14}$ Kongres odbył się 22-23 września 2012 r. w Licheniu. Zgromadził ok. 150 uczestników.
} 


\section{Być zaczynem i duszą społeczności ludzkiej - trzeci etap}

Trzeci rok realizacji trzyletniego programu duszpasterskiego, którego hasłem są słowa „Kościół domem i szkołą komunii”, służyć ma ożywieniu struktur komunijnych tak, by skutecznie służyły ewangelizacji. Struktury istniejące dla samych struktur, niczemu i nikomu autentycznie nie służą. Wpisanie ich w dynamikę ewangelizacji, dzielenia się doświadczeniem Boga, wskazuje na ich zasadniczą rolę. Słowa „Być solą ziemi” - tak zatytułowano trzeci etap programu wskazują na cele, jakie Komisja Duszpasterstwa postawiła przed Kościołem w Polsce na ten okres pracy pastoralnej. To przede wszystkim krzewienie duchowości komunii, rozbudzanie ducha apostolskiego wiernych świeckich, formowanie wiernych zdolnych do czynnego zaangażowania się w przemianę świata oraz uwrażliwianie na najbardziej potrzebujących. Wskazano również treści, na które należy zwrócić szczególną uwagę w realizacji programu. Są nimi: nadprzyrodzona miłość świata, powszechne powołanie apostolskie, ewangelizacja wielowymiarowa, zaangażowanie społeczne chrześcijan, służba ubogim, a także troska o rodzinę. Aby móc osiągnąć zamierzone cele wskazano nadto ścieżki ich realizacji. Wśród nich wymieniono odkrywanie powołań do ewangelizacji, wspólną troskę wierzących o przekaz wiary młodemu pokoleniu, chrześcijańskie świadectwo małżeństw i rodzin, obecność wiernych świeckich w życiu społecznym, politycznym, gospodarczym, kulturalnym, medialnym, umacnianie i rozszerzanie działalności parafialnych zespołów Caritas oraz troskę o chrześcijańskie przeżywanie niedzieli ${ }^{15}$.

Duchowe korzenie, będące konsekwencją autentycznej komunii z Bogiem, które owocują powstaniem struktur komunijnych, sprawiają, że struktury te służą temu, do czego zostały powołane - realizacji zbawczej misji Kościoła w wymiarze diecezji czy parafii. Myślenie członków Komisji Duszpasterstwa było proste: $\mathrm{w}$ trzecim roku realizacji programu winniśmy pokazać, że jesteśmy zarówno blisko Boga, jak i człowieka, zjednoczeni z Bogiem i solidarni z człowiekiem.

Szczególny akcent położono na przekaz wiary młodemu pokoleniu, starając się podjąć debatę $\mathrm{w}$ diecezjach, parafiach i rodzinach na temat przygotowania młodzieży do bierzmowania. Wszędzie w naszych parafiach przygotowanie do tego sakramentu sprawia wiele trudności i przynosi niezbyt obfite owoce. Bardzo często brakuje nam krytycznej, a zarazem odpowiedzialnej i lojalnej dyskusji na temat realizacji misji Kościoła. Program sugeruje, że taka debata w środowiskach Kościołów lokalnych jest niezbędna. W publikacji programu, Komisja Duszpa-

${ }^{15}$ Por. Sz. S t u $\nmid$ k o w s k i: Schemat programu duszpasterskiego. Być sola ziemi. W: Być sola ziemi. Kościół domem i szkoła komunii. Program duszpasterski Kościoła w Polsce na lata 20102013. Red. Sz. S t u ł k o w s k i. Poznań 2012 s. 19-20. 
sterstwa zaproponowała pewne sprawdzone metody pracy, z których można skorzystać w przekazie wiary młodym ludziom ${ }^{16}$.

Drugim kluczowym zagadnieniem trzeciego etapu realizacji programu jest solidarność z potrzebującymi. Opublikowany na prośbę Komisji Duszpasterstwa raport z działalności Caritas, ukazuje ogromne bogactwo, jakim dysponuje Kościół w postaci osób, które się w tę posługę angażują. Nie brakuje różnorakich działań, projektów i interwencji i wreszcie środków materialnych przekazanych przez ludzi wierzących w Boga na działalność charytatywną ${ }^{17}$. Jak zaznaczył w słowie wstępnym do programu abp Stanisław Gądecki: chcemy także wesprzeć ogromne wysitki, jakie podejmuje we wszystkich naszych diecezjach Caritas Polska, by skutecznie troszczyć się o potrzebujacych. Aż nie chce się wierzyć, że w sytuacji tak poważnych i licznych problemów zwiazanych z ubóstwem, połowa polskich parafii formalnie nie posiada Parafialnych Zespotów Caritas ${ }^{18}$. Te dwa celowo wybrane zadania Kościoła - przekaz wiary młodym ludziom oraz opcja na rzecz ubogich - pokazują, jak wiele jest do zrobienia w naszych wspólnotach parafialnych, by móc powiedzieć ze spokojnym sumieniem, że jesteśmy solą ziemi.

Wizja Kościoła, jaką zostawił nam Chrystus podczas Ostatniej Wieczerzy w wieczerniku jest bardzo konkretna: Jego Kościół ma być mistyczny i służebny. Mistyczny doświadczeniem słowa Bożego i sakramentów, zwłaszcza Eucharystii oraz służebny obmywaniem nóg, a więc zaangażowaniem na rzecz potrzebujących. W tej wizji jest też bardzo konkretna zależność: im bardziej mistyczny, tym bardziej służebny.

Ta krótka analiza celów, treści i realizacji trzyletniego programu duszpasterskiego dla Kościoła w Polsce (2010-2013) wyraźnie pokazuje, że nie sposób zrealizować tak podstawowych założeń pastoralnych w przeciągu zaledwie trzech lat. Obrana przez Komisję Duszpasterstwa dynamika programu - od mistycznych korzeni do apostolskich owoców - jest słuszna i winna przemieniać Kościół mocą samego Boga. Jednak brak w polskim duszpasterstwie determinacji i odwagi, aby wsłuchując się głos Ducha Świętego i czytając znaki czasu tworzyć wizję Kościoła przyszłości, nie ułatwia owocnej realizacji programu duszpasterskiego.

\footnotetext{
${ }^{16}$ Por. A. S e p i oł o: Otworzyć młodych na Ducha Świętego. Trzyletni program dla parafii»Młodzi na progu«. W: Być sola ziemi, tamże, s. 282-290.

${ }^{17}$ Por. Z. S o b o l e w s k i: Caritas: chcemy być »sola ziemi«. W: Być sola ziemi, tamże, s. 317-354.

${ }^{18}$ S. G ą d e c k i: Stowo wstępne. W: Być sola ziemi, tamże, s. 11.
} 